Technical Report: Agreement No. 4202-34906

\title{
PROPOSED IMPLEMENTATION OF THE INDIANA EROSION AND SEDIMENT CONTROL FIELD GUIDE
}

\author{
by \\ Lynn A. Corson, Ph.D. \\ Environmental Management Concepts, LLC \\ 6678 West 200 North \\ Delphi, Indiana 46923 \\ Joint Transportation Research Program \\ Project No. C-36-68-EE \\ File No. 4-7-31 \\ Indiana SPR-3476 \\ Conducted in Cooperation with the \\ Indiana Department of Transportation \\ and the U.S. Department of Transportation \\ Federal Highway Administration
}

The contents of this report reflect the views of the author who is responsible for the facts and accuracy of the data presented herein. The contents do not necessarily reflect the official views or policies of the Indiana Department of Transportation and Federal Highway Administration. This report does not constitute a standard, specification or regulation.

July 2010 


\section{TABLE OF CONTENTS}

Introduction $\quad 3$

Objectives or Purpose 5

$\begin{array}{ll}\text { Work Plan } & 6\end{array}$

$\begin{array}{ll}\text { Conclusion } & 11\end{array}$ 


\section{PROPOSED IMPLEMENTATION OF THE INDIANA EROSION AND SEDIMENT CONTROL FIELD GUIDE}

$\underline{\text { Introduction }}$

Recommendations for the contents of an Indiana Erosion and Sediment Control Field Guide is one of five deliverables stipulated in the Joint Transportation Research Project (JTRP) proposal for SPR-3312, Identification and Implementation of Best Management Practices for Erosion and Sediment Control that Conform to Indiana Stormwater Quality Regulations and Guidance, along with recommendations for updates to the Standard Specifications, revision of the descriptions of Best Management Practices (BMPs) to comport with the Indiana Department of Environmental Management (IDEM) Stormwater Quality Manual, a revised National Pollutant Discharge Elimination System (NPDES) stormwater permit application and recommendations for an Erosion and Sediment Control training curriculum.

The Field Guide is intended to be used by contractor personnel in assessing site conditions and to select and install the appropriate erosion and sediment control BMPs and by the Indiana Department Of Transportation (INDOT) field personnel responsible for supervising and inspecting the selection/installation.

A preliminary, non-technical review of the Kentucky Field Guide as a framework for Indiana by the Principal Investigator (PI), who was also the PI for SPR-3312, revealed changes needed in references to statutes and Standards, replacement of residential development photos with highway construction photos and comparison of construction standards between the two states for slopes, seeding rates, aggregate size, etc. The PI asked SPR-3312 contractor Christopher B. Burke Engineering, Ltd. (CBBEL), to conduct 
a more thorough review and make the necessary changes, recognizing that the additional cost incurred in making the second round of changes to the Standards and descriptions of the BMPs reduced the funds available for making the changes to the Kentucky Field Guide. Limited changes were made before the expiration of the SPR-3312 study. This work supported the development of recommendations for changes to the Kentucky Field Guide intended to improve and facilitate the selection/installation of erosion and sediment control measures by contractors and the supervision/inspection of contractor activity by INDOT personnel while at the construction site without the need to access other documents manually or electronically from the construction project trailer or elsewhere. The Indiana Field Guide will help INDOT comply with statutory requirements and avoid the violation notices and associated penalties affixed for noncompliance, as well as provide better and more immediate erosion and sediment control at construction sites. 


\section{Objectives or Purpose}

The subcontractor, Environmental Management Concepts, LLC (EMC), will complete the development of recommendations for changes to the Kentucky Erosion Prevention and Sediment Control Field Guide for the Indiana Temporary Erosion and Sediment Control Field Guide to be used by INDOT and contractor personnel at highway construction sites.

The work plan tasks include:

1. researching appropriate references to INDOT Standard Specifications, the Design Manual, other INDOT documents and Indiana environmental statutes;

2. researching internet links for INDOT documents and Indiana statutes and developing a web-links page for inclusion in the Field Guide;

3. replacing residential development photographs used in the Kentucky Field Guide with highway construction photos for the Indiana guide;

4. replacing Kentucky construction standards with Indiana standards for slopes, seeding rates, aggregate size, etc.;

5. finalizing copy changes and proof-reading content;

6. publishing a master copy for electronic transfer to INDOT files.

The work time schedule for the above tasks is April 1 - June 30, 2010. 


\section{$\underline{\text { Work Plan }}$}

1. The Kentucky Erosion Prevention and Sediment Control Field Guide, published by the Technology Transfer Program, Kentucky Transportation Center at the University of Kentucky, was selected as a "model" for the Indiana Temporary Erosion and Sediment Control Field Guide because of its pocket-sized format, "thumbs-up/thumbs-down" photo depictions of erosion and sediment control structure installation and the willingness and cooperation of the staff at the Kentucky Transportation Center to allow Indiana to use the Kentucky format.

The Kentucky Field Guide is intended to provide guidance to construction contractors of residential, commercial and highway development projects. The Indiana Field Guide was intended to focus exclusively on linear highway construction projects pursuant to contracts with INDOT.

The Kentucky Field Guide included references to the environmental regulations, construction standards and project design specifications required by that state, but many of these were not relevant to Indiana.

The consultant for the allied SPR-3312 JTRP project, CBBEL, reviewed the Kentucky Field Guide and made some changes, inserting references to regulations, standards and specifications applicable to Indiana; however, the work was incomplete when the SPR-3312 project ended.

The PI continued the research, with occasional assistance from the staff of the INDOT Office of Environmental Services and the IDEM Office of Water Quality in identifying relevant standards, specifications and regulations. 
2. The Kentucky Field Guide included a chapter and appendixes containing much of the text of the state standards, specifications and regulations. Given the location of such information on the internet and its accessibility via electronic devices at the construction site, a decision was made to reduce the number of pages in the Indiana version and include only a web-links page. INDOT and IDEM staff and other Study Advisory Committee (SAC) members assisted in the identification of relevant weblinks.

3. Because of the orientation of the Kentucky Field Guide to general construction, many of the "thumbs-up/thumbs-down" photographs depicting erosion and sediment control structures include housing subdivisions, public parks and commercial development, which the PI suggested be replaced with others of linear highway construction projects. Having no immediate source for such photos and preferring that the selection of replacement photos be made by those having experience with such projects, the PI requested assistance from INDOT and IDEM. The draft field guide prepared by this JTRP study and provided to INDOT still contains 17 "photo placeholders" awaiting selection of the replacement photos.

4. Except for "universal" standards common to highway construction projects in most states - - usually promulgated by the American Association of State Highway Transportation Officials (AASHTO) - - there are variations between the states in standards affecting slopes (gradients), grass seeding rates, aggregate (stone) size for various applications, the approved use of certain erosion and sediment control devices (e.g., straw bales cannot be used in Kentucky and can be, but are not preferred, in Indiana) and others. 
The Indiana Field Guide is a "guidance manual," not a contract document; i.e., its contents cannot be enforced or used as a defense of performance. The contracts between INDOT and its contractors and the citations of regulations, standards and specifications contained in those contracts are the only enforceable/defendable documents. The guidance, however, needs to be accurate so decisions can be made at the construction site without causing a delay, such as by having to consult others at the contractor's headquarters. The Field Guide is also intended to provide guidance to INDOT and IDEM field staff conducting inspections of construction projects to ensure compliance/conformance with state and federal environmental regulations and INDOT standards and specifications.

The PI asked, first, CBBEL consultant staff, then INDOT and IDEM staff and other SAC members (e.g., Indiana Construction Association) to review the construction standards cited in the Field Guide and confirm their accuracy. The PI also compared every Field Guide reference to a standard with the 2010 INDOT Standard Specifications and the 2010 Indiana Design Manual. Discrepancies between the field guide statements and actual standards or specifications were corrected; a few discrepancies were referred to INDOT staff for their review and resolution.

5. Four drafts of the Indiana Field Guide were provided for review, both in PDF and in Adobe InDesign publishing software. INDOT and IDEM staff and SAC members were notified when each version was posted on the internet for their review; few responses were received. 
6. The PI proceeded to finalize the draft of the Indiana Field Guide and the final product of this JTRP project was delivered to INDOT on June 30, 2010, on a "flash drive" with the following instructions:

"A flash drive of the Indiana Field Guide is enclosed. It contains:

- a Folder (Field Guide Flash Drive Information) containing a flash drive information "fact sheet"

- a Folder containing fonts (Fonts) used in the Field Guide (these are embedded in the InDesign [indd] version of the Field Guide in the IN Field Guide DRAFT 050610 Folder)

- a Folder (IN Field guide DRAFT 050610 Folder) containing a Fonts Folder (Fonts that are embedded in the Field Guide, Links Folder (Links that are embedded in the Field Guide), IN Field Guide Draft 050610.indd (IN Field Guide InDesign version with Fonts and Links embedded) and an instructional text document

- a Folder containing links to photos/graphics CBBEL (Photo_Graphics Links CBBEL directory) used in the Field Guide (these are embedded in the indd version of the Field Guide in the IN Field Guide DRAFT 050610 Folder)

- a Folder containing links to photos/graphics University of Kentucky (Photo_Graphics Links U_KY Directory) used in the Field Guide (these are embedded in the indd version of the Field Guide in the IN Field Guide DRAFT 050610 Folder)

- a Folder containing the IN Field Guide 2010 Draft in PDF (pdf) 
- a Folder containing the IN Field Guide 2010 Draft in InDesign (indd)"

The Adobe InDesign software must be used to open or edit the document in the InDesign version; the document can be viewed or printed in the PDF version. Photos (and Photo place holders) can be inserted, replaced or removed in the InDesign version using the InDesign software. 


\section{$\underline{\text { Conclusion }}$}

INDOT's Office of Environmental Services agreed to oversee the installation of the 17 photos needed to replace the photo place holders, the correction of any technical errors its review discovers and post the final version of the Indiana Temporary Erosion and Sediment Control Field Guide on its website to view or print. 